\title{
The Effect of House Ventilation and Floor Type on the Event of Measles in Jember District
}

\author{
Lailatul Rahmawati, \\ Gufron Wahyudi \\ ${ }^{1}$ Faculty of Public Health, \\ University Bakti Indonesia \\ Email: \\ lailatulrahmawati21@yahoo.co.id
}

Received : October $4^{\text {nd }} 2021$

Accepted : October $15^{\text {rd }} 2021$

Published : November $27^{\text {th }} 2021$

\begin{abstract}
Measles is a disease caused by the measles virus from the Paramyxovirus family, genus Morbilivirus. Measles is one of the communicable disease and one of the main causes of death in children under five. Jember Regency is one of the contributors to measles cases which is quite high, namely in 2015 there were 109 cases, in 2016 there were 266 cases. From 2017 to July there were 342 cases of measles. The incidence is very high compared to 2016. The purpose of the study was to analyze the effect of house ventilation and floor type on the incidence of measles in Jember Regency. The type of research is observational analytic using a Case Control approach which was carried out in the work area of the Jember District Health Center where measles outbreaks occurred in 2017 namely Silo 2 Health Center, Rambi Puji Health Center, Arjasa Health Center, Panti Health Center, Sabrang Health Center, Jelbuk Health Center and Sukorambi Health Center. Samples taken were 100 respondents consisting of 50 case respondents and 50 control respondents. Research data sourced from primary and secondary data, research data collection using questionnaires and documentation studies. Processing and analyzing data using Logistics Regression test with a significance level of $5 \%(\alpha=0.05)$. The results showed that house ventilation ( $p$ value $=0.005)$ had an effect on the incidence of measles in Jember Regency. Home ventilation has an effect on the incidence of measles because some respondents live in homes with inappropriate ventilation and most of them live in homes with ventilation $10 \%$ of the floor area.
\end{abstract}

Keywords: Measles, floor type, communicable disease, air ventilation \begin{abstract}
International License.
\end{abstract}
This is an open-acces article distributed under the terms of the Creative Commons Attribution-ShareAlike 4.0

\section{INTRODUCTION}

Measles virus from the family Paramyxovirus, genus Morbilivirus is a virus that causes measles (Widiyono, 2008). Measles is an infectious disease that can be prevented through immunization. Indonesia has measles immunization coverage which has met the target of $90 \%$, but the measles immunization coverage has decreased each year, namely in 2014 by $94.7 \%$ and in 2015 by $92.3 \%$. The number of measles cases in 2014 was 12,943 cases with 2,104 measles outbreak cases, Incidence Rate (IR) per 100,000 population was 5.13. There were 8,185 cases with 831 cases of 
measles outbreaks and 3.20 measles IRs per 100,000 population with 1 case of death in 2015 (Kemenkes RI, 2015).

The measles immunization coverage of East Java province in 2015 was ranked 11th with a large coverage of $98.43 \%$ where the measles immunization coverage had met the target of $90 \%$, but this coverage figure tends to decrease compared to the immunization coverage in 2014 which was $99.9 \%$. Measles immunization coverage is an illustration of how many children receive measles immunization, immunization can provide immunity up to $90 \%$. The high coverage of measles immunization in East Java province is still followed by high cases of measles that occurred in 2012 as many as 1,085 cases, in 2013 amounting to 2,529 and in 2014 it decreased to 762 cases, many preschool children were attacked by measles (East Java Provincial Health Office, 2014). In 2015 measles cases increased again by 1,072 (Kemenkes RI, 2015).

Jember Regency is one of the high contributors to measles cases, namely in 2010 there were 123 cases, in 2011 there were 128 cases, in 2012 there were 64 cases, in 2013 there were 45 cases, in 2014 there were 112 cases, in 2015 there were 109 cases. 2016 there were 266 cases. In 2017 measles cases from January to August were 342 cases, the number of measles cases was very high compared to 2016 (Jember District Health Office, 2016). The success of the measles immunization program and the incidence of measles are closely related to each other. The success of the measles immunization program can be seen through the coverage of measles immunization. Measles coverage in Jember Regency has increased every year, namely in 2012 by $86.47 \%$ (not yet meeting the set target of 90\%), in 2013 by $90,39 \%, 93.07 \%$ in 2014 and $94.19 \%$ in 2015 (Jember District Health Office, 2016). The high immunization coverage is a picture of high individual immunity (Ningtyas and Arief, 2015). The gap between immunization coverage and the number of measles cases from the results of epidemiological investigations and case investigations illustrates that disease prevention efforts through immunization are still not optimal, and there is still the potential for measles outbreaks. Measles immunization coverage is an illustration of how many children receive measles immunization, where immunization can provide immunity up to $90 \%$. The gap between immunization coverage and the number of measles cases from the results of epidemiological investigations and case investigations illustrates that disease prevention efforts through immunization are still not optimal, and there is still the potential for measles outbreaks to occur. This can occur due to failure factors in immunization, namely due to immunity carried from birth by babies, vaccine damage due to storage, transportation or use outside the guidelines, besides the gap that occurs illustrates that measles risk factors also have an important role in the incidence of measles. In the epidemiological triangle, the incidence of a disease according to Irianto (2014) is influenced by several factors, namely the agent, the host and the environment.

\section{MATERIALS AND METHODS}

This type of research is analytical observational, using a case control approach (case control). In this study, the case group was those who suffered from measles from January to August 2017 in the Jember district, while the control group were respondents who had never had measles. The study was carried out in the work area of the Jember District Health Center where an outbreak occurred in 2017 and the study was conducted from August to December 2017. The total population in this study

totaling 115 respondents with a sample of 50 respondents for the case sample and 50 respondents for the control sample so that the total sample is 100 respondents. The method used in this research is simple random sampling which is then continued by using proportional random sampling method. The research data is sourced from primary and secondary data. The research data is collected using questionnaires and documentation studies. Data processing and analysis using Logistics Regression test with a significance level of $5 \%(\alpha=0.05)$. 
RESULTS

The distribution of the results of the research on home ventilation factors can be seen in table 1 as follows:

\begin{tabular}{lcc}
\hline \multicolumn{1}{c}{ Environmental factor } & $\mathbf{N}$ & $\mathbf{\%}$ \\
\hline Home ventilation & & 0 \\
There is not any & 0 & 40 \\
Yes, the area is < 10\% of the floor area & 40 & 60 \\
Yes, the area is 10\% floor area & 60 & 100 \\
\hline \multicolumn{1}{c}{ Amount } & 100 & 8 \\
\hline Floor type & 8 & 0 \\
Land & 0 & 25 \\
Board/ bamboo/ woven bamboo/ rattan & 25 & 67 \\
Cracked plaster cement & 67 & 100 \\
Ceramic/ tile/ marble/ cement & 100 & \\
\hline Amount & & \\
\hline
\end{tabular}

The results of the research on environmental factors in table 1 show that as many as 60 respondents $(60 \%)$ live in housing with ventilation that is $10 \%$ of the floor area, most of the respondents as many as 60 respondents $(60 \%)$ have ceramic/tile/marble/cement residential floors.

The results of the analysis of home ventilation environmental factors that affect the incidence of measles can be seen in table 2. As follows:

Table 2. Analysis of Home Ventilation Affecting Measles Incidence

\begin{tabular}{|c|c|c|c|c|c|c|c|}
\hline \multirow{3}{*}{ Home Ventilation } & \multicolumn{6}{|c|}{ Measles incident } & \multirow{3}{*}{ P Value } \\
\hline & \multicolumn{2}{|c|}{ Sick } & \multicolumn{2}{|c|}{ Painless } & \multicolumn{2}{|c|}{ Total } & \\
\hline & $\mathbf{n}$ & $\%$ & $\mathbf{n}$ & $\%$ & $\mathbf{N}$ & $\%$ & \\
\hline $\begin{array}{l}\text { Yes, the area is }<10 \% \text { of the floor } \\
\text { area }\end{array}$ & 13 & 32.5 & 27 & 67.5 & 40 & 100 & $0.005^{*}$ \\
\hline Yes, the area is $10 \%$ floor area & 37 & 61.7 & 23 & 38.3 & 60 & 100 & \\
\hline
\end{tabular}

Description $*=$ significant $(\mathrm{p}$ value $<0.05)$

The results of the analysis in table 2 show that most of the respondents have home ventilation with an area of $10 \%$, namely 37 respondents $(61.7 \%)$ suffer from measles and most respondents have home ventilation with an area of $<10 \%$ as many as 27 respondents $(67.5 \%)$.) did not have measles. The results of data analysis using logistic regression test obtained a significance of $0.005(\mathrm{p}<0.05)$ which indicates that there is an effect of house ventilation on the incidence of measles.

The results of the bivariate analysis of floor types that affect the incidence of measles can be seen in table 3. as follows:

Table 3 Analysis of Floor Types Affecting Measles Incidence

\begin{tabular}{|c|c|c|c|c|c|c|c|}
\hline \multirow{3}{*}{ Floor Type } & \multicolumn{4}{|c|}{ Measles incident } & & & \multirow{3}{*}{ P Value } \\
\hline & \multicolumn{2}{|c|}{ Sick } & \multicolumn{2}{|c|}{ Painless } & \multicolumn{2}{|c|}{ Total } & \\
\hline & $\mathbf{N}$ & $\%$ & $\mathbf{N}$ & $\%$ & $\mathbf{N}$ & $\%$ & \\
\hline Land & 4 & 50 & 4 & 50 & 8 & 100 & 0.485 \\
\hline Cracked plaster cement & 9 & 36 & 16 & 64 & 25 & 100 & \\
\hline Ceramic/ tile/ marble/ cement & 37 & 55.2 & 30 & 44.7 & 67 & 100 & \\
\hline
\end{tabular}

The results of the analysis in table 3 show that most respondents have ceramic/tile/marble/cement floors, namely 37 respondents $(55.2 \%)$ suffer from measles and most respondents have ceramic/tile/marble/cement floors as many as 30 respondents $(44,7 \%)$ did not have measles. The results of data analysis using logistic regression test obtained a significance of 0.485 ( $<$ 0.05 ) which indicates that there is no effect of floor type on the incidence of measles. 


\section{DISCUSSION}

The results showed that most of the respondents lived at home with proper ventilation of the house, namely $10 \%$. Houses in rural areas generally have house ventilation and vents in each room, this is very good for air exchange so that the air quality in the house remains good and prevents the growth of microorganisms in the house. respondents have income above the minimum wage. Family income above the minimum wage means that part of the income is used to improve the respondent's residence.

Atmosphere, conditions that are pleasant and healthy for humans are created by ventilation. Adequate ventilation (ventilation) is done to change the air in the room. The requirement for a house that has good air quality is a house that has a room temperature of $18^{\circ}-30^{\circ} \mathrm{C}$ with an air humidity of $40 \%-70 \%$. The recommended ventilation area according to the PERMENKES RI No. 1077 of 2011 is $10 \%$ of the floor area. A house that has an inappropriate ventilation area can affect its occupants (Suyono, 2010). The results of data analysis showed that there was a significant effect of house ventilation on the incidence of measles in Jember Regency, where more than $10 \%$ ventilation would increase the incidence of measles. The results of this study are not in line with the results of research conducted by Setyaningrum (2013) which states that there is a relationship between ventilation and the incidence of measles in the Teras Health Center Work Area, Boyolali Regency, where the risk of measles according to the results of research by Setyaningrum (2013) is 2, 2 times higher for patients with unqualified ventilation than patients with qualified ventilation. The results of this study are supported by research conducted by Budi (2012) which states that children living with poor ventilation have a 0.81 times greater risk of developing measles compared to children in the group with good ventilation. where the risk of measles incidence according to the results of the research by Setyaningrum (2013) is 2.2 times higher in patients with unqualified ventilation than patients with qualified ventilation. The results of this study are supported by research conducted by Budi (2012) which states that children living with poor ventilation have a 0.81 times greater risk of developing measles compared to children in the group with good ventilation. where the risk of measles incidence according to the results of the research by Setyaningrum (2013) is 2.2 times higher in patients with unqualified ventilation than patients with qualified ventilation. The results of this study are supported by research conducted by Budi (2012) which states that children living with poor ventilation have a 0.81 times greater risk of developing measles compared to children in the group with good ventilation.

The difference in these results is probably because most of the respondents live in homes with ventilation that according to the criteria has met the requirements and the area is more than $10 \%$ of the floor area, but the ventilation area which in this study consists of permanent ventilation (vent) is only about $2 \%$ of the floor area. while for ventilation opening and closing about $8 \%$. Ventilation with an area of more than $10 \%$ of the floor area is mostly not opened and only a few houses have ventilation holes in the house so that the conditions in the house are humid and sunlight tends not to enter the house, so that the real ventilation is $<10 \%$, or there is a bias in determining ventilation criteria. Some of the respondents live in homes that have less ventilation. Inappropriate ventilation causes microorganisms to thrive which can cause disruption to human health (PERMENKES RI, 2011). According to the opinion of Winslow and the American Public Health Association (APHA) which states that a good ventilation requirement is ventilation of more than $10 \%$ consisting of permanent ventilation with an area of 5\% of the floor area and 5\% incidental ventilation (Machfoedz, 2008). This is also in accordance with the results of research conducted by Ardiyanto (2016) which states that poor ventilation can prolong virus activity in the house. Ventilation that meets the requirements and is used properly not only allows the exchange of dirty air from inside the house,

The Decree of the Minister of Health of the Republic of Indonesia No. 829 of 1999 concerning the requirements for residential houses states that the requirements for a good floor are those that are easy to clean and are not waterproof, such as ceramic floors, sealed wood, tiles or cement that are impermeable and strong. The floor of the house that is not waterproof and difficult to clean will be a place for the development and growth of microorganisms in the house.

The results of data analysis showed that there was no effect of floor type on the incidence of measles in Jember Regency. This is because most of the respondents already have houses with ceramic/tile/cement floors. Clean floor conditions and floor conditions that have met good floor requirements can reduce the growth of disease microorganisms. This is in accordance with KEPMENKES No. 829 of 1999 which states that the requirements for a good floor are watertight, easy to clean. The respondent's habit of not opening ventilation in the morning makes the condition of the 
house stale and humid so that it can affect the growth of microorganisms that cause disease, This is in accordance with research conducted by Ardiyanto (2016) which states that poor ventilation can prolong virus activity in the house. Some respondents still have a type of dirt floor, this can facilitate the development of disease if cleanliness, humidity is poor. The type of floor has a role in the incidence of measles, the ground floor tends to cause humidity. The floor during the summer can turn dry so that it can cause dust that is harmful to the occupants, this can easily transmit measles (Heniwati, 2016).

\section{CONCLUSION}

The conclusion of this study is that there is a significant effect of house ventilation on the incidence of measles in Jember Regency, where ventilation of more than $10 \%$ will increase the incidence of measles, but house ventilation has an effect on the incidence of measles because some respondents live in homes with inappropriate ventilation and most of the respondents live in homes with inadequate ventilation. live in a house with ventilation $10 \%$ of the floor area. The ventilation is never opened, causing microorganisms in the house to easily grow in the house.

\section{CONFLICTS OF INTEREST:}

The author declares that they have no conflict of interest

\section{REFERENCES}

Ardiyanto, B. S. 2016. Analisis Faktor Resiko dengan Kejadian Campak di Kabupaten Boyolali. Skripsi. Surakarta: Fakultas Ilmu Kesehatan Masyarakat: Universitas Muhammadiyah Surakarta

Budi, D. A. G. 2012. Faktor-Faktor yang Berpengaruh terhadap Kejadian Campak pada Peristiwa kejadian Luar Biasa Campak Anak (0-59 Bulan) di Kota Banjarmasin Provinsi Kalimantan Selatan Tahun 2011. Tesis. Depok: Fakultas Kesahatn Masyarakat, Program Pascasarjana Universitas Indonesia

Dinas Kesehatan Kabupaten Jember. 2016. Laporan Seksi P3KL Kabupaten Jember 2016. Jember: Dinas Kesehatan Jember

Dinas Kesehatan Kabupaten Jember. 2016. Imunisasi Campak Tahun 2013 s/d 2015 dan Kasus Kejadian Campak Tahun 2013 s/d 2011. Jember: Dinas Kesehatan kabupaten Jember

Heniwati, L. 2016. Analisis Spasiotemporal Kejadian Campak di Provinsi jawa Timur Tahun 20092013. Jember: Skripsi. Fakultas kesehatan Masyarakat, Universitas Jember

Irianto K. 2014. Epidemiologi Penyakit Menular Dan Tidak Menular Panduan Klinis. Bandung: Penerbit Alfabeta

Keputusan Menteri Kesehatan No. 829 Tahun 1999. Persyaratan Kesehatan Perumahan. Jakarta

Kementrian Kesehatan RI. 2015. Profil Kesehatan Indonesia 2015. Jakarta: Kementrian Kesehatan Republik Indonesia

Machfoedz, I. 2008. Menjaga Kesehatan Rumah dari Berbagai Penyakit Kesehatan LingkunganKesehatan Masyarakat Sanitasi Pedesaan dan Perkotaan. Jakarta: Fitramaya

Ningtyas, DW dan Arif, W. 2015. Pengaruh Kualitas Vaksin Campak terhadap Kejadian Campak di Kabupaten Pasuruan. Surabaya: Unair

Peraturan Menteri Kesehatan Republik Indonesia No. 1077 Tahun 2011. Pedoman Penyehatan Udara dalam Ruang Rumah. Jakarta 
Setyaningrum. 2013. Faktor-Faktor yang Berhubungan dengan Penyakit Campak di Wilayah Kerja Puskesmas Kecamatan teras Kabupaten Boyolali. Skripsi. Surakarta: Fakultas Ilmu Kesehatan: Universitas Muhammadiyah Surakarta.

Suyono, dan Budiman. 2010. Ilmu Kesehatan Masyarakat. Jakarta: EGC

Widiyono. 2008. Penyakit Tropis; Epidemiologi, Penularan, Pencegahan \& Pemberantasannya. Jakarta: Penerbit Erlangga 